\title{
ФУНКЦІОНУВАННЯ ЛЕКСЕМ У СИСТЕМІ НАЙМЕНУВАНЬ ВУЛИЦЬ
}

Жила Т. І. Функціонування лексем у системі найменувань вулиць.

У статті розглянуто особливості функціонування лексем на позначення вулиці, що входять у систему найменувань адміністративно-територіальних одиниць у межах населених пунктів. Простежено семантику лексем, стилістичне використання.

Ключові слова: лексико-семантична група, адміністративно- територіальна лексика, семантична структура, адресна функція.

Жила Т. И. Функционирование лексем в системе наименований улиц.

В статье рассматриваются особенности функционирования лексем для обозначения улиц, входящие в систему наименования единиц административного деления на территории населенных пунктов. Прослежена семантика лексем, стилистическое использование.

Ключевые слова: лексико-семантическая группа, административно-территориальная лексика, семантическая структура, адресная функция.

Zhila T. I. The lexemes functioning for denotation of the streets.

The features of lexemes functioning for denotation of street which are included in the system of names of administrative-territorial units within settlements are considered in the article. The semantics of lexeme, its stylistic use is traced.

Key words: lexical-semantic group, administrative-territorial lexis, semantic structure, address function.

Вивчення історії формування словникового складу мови $\epsilon$ актуальним у сучасній мовознавчій науці. Нині лінгвістичними студіями охоплено широке коло лексики, яка відображає різноманітні сторони життя і діяльності людей. У численних монографіях і статтях українські та

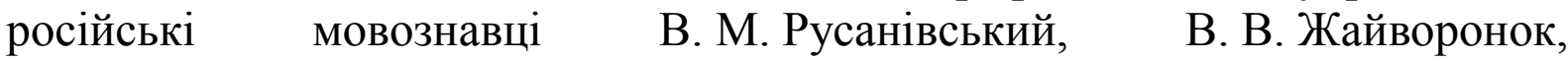
А. А. Уфимцева, Д. М. Шмельов та ін. досліджували історію формування різних тематичних груп лексики. Існують праці, присвячені лексиці на позначення територіальних одиниць. Це дослідження В.В.Богачука, Л.Л.Гумецької， Л. І. Батюк， Л.С.Паламарчука. На матеріалі списків київських вулиць XIX та XX ст., історико-географічних описів Києва, карт, планів міста X - XIV ст. проаналізувала словотвірну структуру власних назв київських вулиць, провулків, бульварів у статті «Словотвірна структура топонімів адресного функціонування (назви вулиць міста Києва)» Л. І. Колоколова [2, с. 87-94]. Усі лінгвісти сходяться на думці, що словниковий склад мови тісно пов'язаний з позамовними чинниками: історією народу, культурою, побутом, суспільним життям.

Найбільш уживаною назвою на позначення одиниць поділу в межах як сільського, так і міського поселення, є іменник вулиця. Для вулиць, які відрізняються якимись ознаками від звичних, вживаються спеціальні назви.

Лексема улица зафіксована словниками XVI-XVII ст. Так, у Л. Зизанія іменник халуга реєстровий, а його відповідник оулиия (ЛЗ, 84). У П. Беринди реєстровому халуга у перекладній частині відповідає ряд улиия, заплута, заулок (ЛБ, 143), а реєстрове стогна перекладено словами площадь, улиия і зроблено відсилку до халуга (121). Іменниками стогна, 
халуга, площзадь перекладено у «Лексиконі латинському» лат. plate (ЛС, 319), а в «Лексиконі словено-латинському» реєстрові стогна і улиия поміщені в одній статті і лексикограф відсилає до лексеми площуадь (ЛК, 512). У «Лексиконі» П. Беринди окремо фіксується іменник площада - широка улица і окремо площзадь - улица (ЛБ, 85). Отже, ми можемо встановити, що синоніми халуга, стогна, улиця, площзадь, заплута, заулок були назвами одиниць територіального поділу у межах села чи міста, проте особливості тлумачень не дозволяють визначити семантичні відмінності цих слів.

На позначення вулиці функціонував іменник стогна. Із позначкою засm. лексема стогна зареєстрована в Словнику української мови зі значенням «широкі вулиці, майдани». Паспортизується контекстами 3 поезій Т. Шевченка, М. Старицького: Не видно ніколи в Ієрусалимі, Врата на запорі, неначе чума в Давидовім граді ... засіла на стогнах (Т. Шевченко); Настане час, $і$ з тим новим псаломом ми підемо по стогнах городів (М. Старицький) (СУМ, IX, 724). С це слово і в романі П. Куліша «Чорна рада»: ... Скілько-то на твоїх улицях, на тих старосвітських стогнах пролито крові християнської (Куліш, 26).

Крім іменника вулиця, відомі також однокореневі провулок, завулок. У «Словнику української мови» слово провулок зареєстровано зі значенням «обмежений двома рядами будинків простір для їзди та ходіння», а також демінутив провулочок (СУМ, VIII, 144). У системі адміністративнотериторіальної лексики функціонує як офіційне найменування із власною назвою: Аскольдів провулок (кол. Панкратьєвський пров.). ... Названий на честь Аскольда (КЕ, 49); провулок Кріпосний, провулок Козловського, провулок Музейний, провулок Виноградний (Київ); провулок Садовий (Умань); провулок Меблевий (Житомир). Рідше вживається іменник завулок (рідше - заулок, закоулок), напр.: Ідуть наші прочани по тих закоулках, аж дивляться посеред улиці збились вози у купу (Куліш, 27); 3 вулиці Карла Лібкнехта вони звернули цे пішли по глухих нагірних заулках (Хвильовий, 281); Перепродує мислі підтерті у завулках тісних передмість (Симоненко, 131). Лексема завулок (рідко - заулок) функціонує зі значенням «прохід між двома вулицями» (СУМ, III, 62). Як офіційна назва не вживається.

Іменник майдан, на позначення міської реалії, може позначати не площу взагалі, а територіальну одиницю в структурі міста, вживатися 3 власною назвою і виконувати адресну функцію апелятива вулиця: Майдан Незалежності (Київ); майдан Шептицького (Калуш), напр.: ... зі своӥм приятелем Ровінським Борисом, рудим підлітком із майдану Зарембського (Даниленко, 160); м. Житомир, майдан Путятинський, 3 (УК, 17.06.05, 15).

Іменник площзадь зареєстровано у словнику I. I. Срезневського зі значенням «ровное, незастроенное мһсто, площадь, улица» (Срезн., II, 970). В. В. Богачук відзначає, що площза є частиною міського 
планування [1, с. 153]. У «Словнику української мови» відзначено, що площа - це велике незабудоване місце, безпосередньо зв’язане з вулицями; майдан (СУМ, VI, 594).

Адресні дані засвідчують, що слово площуа, вживаючись із позначенням номера будинку, позначає не власне площу «незабудоване місце», а, виконуючи адресну функцію, стає синонімом слову вулиця: Бессарабська площа, буд. 5, 7, 7a (Київ); Московська площуа, 3 (Київ); Вокзальна площча, 2 (Київ); площза Леніна, 1 (Умань); площуа Комунарів, 1 (Донецьк).

Прикметою великих міст є наявність вулиць, які позначаються назвами бульвар, проспект. Ці найменування у сполуці з власною назвою вживаються в системі адміністративного поділу, виконуючи адресну функцію.

За даними «Словника іншомовних слів», назва бульвар запозичена 3 французької мови й уживається зі значенням «алея посеред вулиці; широка вулиця, обсаджена деревами» (CIC, 191). Г. П. Циганенко, простежуючи семантичні зміни етимона в мові, що запозичила, вказує, що це частина міської вулиці з доріжками для пішоходів (ЕСРМ, 44). В офіційному мовленні бульвар уживається 3 власною назвою, напр.: бульвар Шевченка (Черкаси), бульвар Тараса Шевченка (Київ), бульвар Лесі Українки (Київ).

Назва бульвар засвідчена художніми текстами, в яких вона виступає як елемент змалювання міської культури, напр.: Вечоріло, коли ми $з$ Бориком тинялися містом у пошуках пригод. На бульварі побачили Степана (Даниленко, 165). Утворилося похідне слово бульварчик: I оm один час почав я ходити в один бульварчик на перехресті трьох вулицьь (Винниченко, 235).

У систему найменувань вулиць зрідка залучається слово алея. У «Словнику української мови» воно зафіксовано зі значенням «дорога в садку, парку, обсаджена з обох боків деревами, кущами» (СУМ, I, 33). У системі територіальної лексики цей номен розширює свою семантику i позначає не власне дорогу, а разом із власною назвою служить для найменування вулиці: ... вулиця, щуо простягається від Петровської алеї до Дніпровського узвозу уздовж схилів Дніпра. Колись частина вулиці, щзо починалась від Петровської алеї, називалась Козловською (Печерськ, вересень 2004, 6).

Поширеною назвою сучасних міських вулиць $є$ проспект. У «Словнику іншомовних слів» вказано, що ця назва запозичена з латинської мови і вживається в українській мові зі значенням «пряма, довга і широка міська вулиця» (CIC, 769). Багато міських вулиць іменуються проспектами. Заступаючи апелятив вулиця, у системі адміністративно-територіальної лексики номен проспект виконує адресну функцію: проспект Науки, проспект 40-річчя Жовтня (Київ); проспект Ватутіна (Ватутіно); проспект Гагаріна (Харків); проспект Леніна (Запоріжжя).

В аналізованій нами групі лексики функціонує синонімічний ряд слів на позначення доріг, напр. шосе, дорога, шлях. Крім номінативної, в системі 
адміністративно-територіальної лексики ці назви виконують адресну функцію. Назви шосе, шлях, дорога засвідчені у складі урбанонімів у містах України, напр.: Нікопольське шосе (Кривий Ріг), Набережне шосе, Залізничне шосе, Столичне шосе (Київ), Хмельницьке шосе (Вінниця), Олександрійське шосе (Кіровоград), Ленінградське шосе (Умань). Без апелятива вуличя засвідчені такі назви в художніх творах: Блукав коло вокзала, подорожував Берестейським шосе (Підмогильний, 464);

«Словник іншомовних слів» фіксує назву шосе зі значенням «автомобільна дорога $з$ твердим покриттям» і вказує, що вона запозичена 3 французької мови (СIC, 985).

В адресній функції, заміщаючи апелятив вулиця, виступає іменник дорога. «Словник української мови» слово дорога реєструє зі значенням «смуга землі, по якій їздять і ходять // штучно створений засіб для пересування, місце для проходу, проїзду» (СУМ, II, 378). Отже, у словниковій статті не відображено функціонування іменника дорога в системі адміністративно-територіальної лексики. Номен дорога вживається у складі урбанонімів у містах України, напр.: Набережно-Печерська дорога (Київ), Дніпропетровська дорога (Одеса). Місчевість, щзо була відома в старому Києві під назвою Провалля - нині изе Паркова дорога, вулиця, щзо простягається від Петровської алеї до Дніпровського узвозу уздовж схилів Дніпра. Назва «Паркова дорога» пов'язана $з$ Першотравневим і Радянським парками (нині Міський сад і Маріїнський парк), на схилах яких ї̈ прокладено.У 1963 роцуі Паркова дорога $i$ Козловські вулицяя стали єдиною вулицею (Печерськ, вересень 2004, 6).

Такі ж функції може виконувати іменник илях, напр.: Добрий илях. вулиия в Московському районі, простягається від Голосї̈вької до Блакитного вулищі (КЕ, 172); Кіквідзе вулицяя ... Відома з початку $20 \mathrm{~cm}$. під назвою Військовий шлях (КЕ, 287); Полтавський илях (Харків). У «Словнику української мови» в лексемі илях виокремлено значення «смуга землі, призначена для їзди та ходіння; дорога» та «місце для проходу, проїзду кого-, чого-небудь; прохід» (XI, 493).

Рідше представлено інші назви, напр. проїзд. У «Словнику української мови» зареєстровано зі значенням «невелика вулиця, що 3’єднує дві вулиці; провулок» (VIII, 190).

У «Словнику української мови» лексема тупик із ремаркою рідко реєструється зі значенням «вулиця, провулок, що не мають наскрізного проходу, проїзду» (X, 321). Іменник тупик може бути загальною назвою вулиці: Дуки Степана вулицяя (кол. Агрономічний пров.). простягається від вул. Китаӥвської до тупика (Московський р-н) (КЕ, 181); Номен тупик може виконувати також адресну функцію, вживаючись у складі власної назви без апелятива вулиця: Тверський тупик (Київ), Залізничний тупик (Умань).

На позначення вулиць у складі їх власних назв можуть бути слова, які поза контекстом з вулицею не співвідносяться, проте в найменуванні вулиць 
уживаються без компонента вулиця, наприклад балка. Функціонує у словосполученні на позначення вулиці: Гостро порушували питання про забудову мешканці Старонаводницької балки (Печерськ, березень 2005, 4).

У системі досліджуваної лексики спостерігається перенесення назв, що позначають особливості рельєфу, на позначення території, місцевості. Існують спеціальні назви для вулиць, які відзначаються особливостями рельєфу. Це давнє слово узвіз: Боричів узвіз. Тепер простягається від Боричевого току до Набережно-Хрещзатицьької вул. (КЕ, 71).

Рідкісною назвою на позначення вулиці є слово тік, напр.: Боричів тік. Вулиия в Подільському р-ні. Відома з часів Київської Русі (КЕ, 71).

У такій же функції вживається і слово яр, напр.: Кмитів яр. Вулиия в Шевченківському районі (КЕ, 293), Протасів яр (Київ).

Сполуки з іменником вал можуть уживатися як $з$ апелятивом вулиия, так і без нього, напр.: Верхнє місто. Займало територію, обмежену сучасною вулицею Ярославів вал, Львівською площуею (ЕК, 93).

Отже, у межах міських поселень є вулиці, які відрізняються якимись ознаками від звичних. Для їх номінації вживаються назви, які можуть функціонувати i в офіційній сфері у сполуці 3 власними назвами, заміщаючи апелятив вулицяя.

\section{Література}

1. Богачук В. В. Нарицательные наименования населенных пунктов и их частей в памятниках русской народности XIV-XV вв. : дисс. ... канд. филол. наук / В. В. Богачук. - К., 1972. - 232 с.

2. Колоколова Л. И. Словопроизводная структура топонимов адресного функционирования (названия улиц города Киева) / Л. И. Колоколова // Русское языкознание. - 1980. - Вып. 2. - С. 87-94.

\section{Лексикографічі джерела}

ECРM Ц Цыганенко Г. П. Этимологический словарь русского языка / Г. П. Цыганенко. - К. : Радянська школа, 1989. - 511 с.

ЕСУМ Етимологічний словник української мови : у 7-ти т. / [за ред. О. С. Мельничука]. - К. : Наукова думка, 1982-2003. - Т. 1-4.

ЛБ Лексикон словенороський Памви Беринди / [підг. тексту і вступна стаття В. В. Німчука]. - К. : Наукова думка, 1961. - 272 с.

Л3 Лексис сирьчъ Реченїл, Въкратць събранны. И из слове(н)скаго газыка, напросты Рискій Ділле(к)тъ Истолкованы. Л. Z. // Лексис Лаврентія Зизанія. Синоніма Славеноросская / Підгот. до вид. В. В. Німчук. - К. : Наукова думка, 1964. - С. 23-93.

ЛК Лексикон словено-латинський Є. Славинецького та А. Корецького-Сатановського // Лексикон латинський Є. Славинецького. Лексикон латинський Є. Славинецького та А. КорецькогоСатановського / Підгот. до вид. В.В. Німчук. - К. : Наукова думка, 1973. - С. 421-540.

ЛС Лексикон латинський Є. Славинецького. Лексикон латинський Є. Славинецького та А. Корецького-Сатановського / Підгот. до вид. В. В. Німчук. - К. : Наукова думка, 1973. - 541 с.

CIC Словник іншомовних слів / [уклад. Л.І. Пустовіт та ін.]. - К. : Довіра, 2000. - 1018 с.

Срезн. Материалы для словаря древнерусского языка. - СПб., 1895-1912. - Т. І-III.

СУМ Словник української мови / [за ред. І. К. Білодіда]. - К. : Наукова думка, 1970-1980. - Т. 1-11.

\section{Джерела дослідження}

Винниченко - Винниченко В. Рабині Справжнього // Український Декамерон / Упоряд. Р. Піхманець. - К. : Довіра, 1993. - Кн. I : Дияволиця. Новели. Повість / Післямова І. Денисюка. С. 231-246.

Даниленко - Даниленко В. Віолетта 3 драндулета (Магічне оповідання) / В. Даниленко // Українська мова й література в середніх школах, гімназіях, ліцеях та колегіумах. - 2000. - № 3. C. $160-168$.

КЕ - Київ : Енциклопедичний довідник / За ред. А. В. Кудрицького. - К. : Гол. редакція УРЕ, 1981. 
Куліш - Куліш П. О. Твори : у 2-х т. - К. : Дніпро, 1989. - Т. 2 : Чорна рада : Хроніка 1663 року; Оповідання; Драматичні твори; Статті та рецензії. - 586 с.

Підмогильний - Підмогильний В. П. Оповідання. Повість. Романи. - К. : Наукова думка, 1991. - 800 с.

Симоненко - Симоненко В. Ти знаєш, що ти - людина : Вірші, сонети, поеми, байки / Передм.

В. А. Гончаренка. - К. : Наукова думка, 2005. - 296 с.

УК - газета «Урядовий кур'єр».

Хвильовий - Хвильовий М. Г. Твори : у 2-х т. - К. : Дніпро, 1990. - Т. 2 : Повість. Оповідання. Незакінчені твори. Нариси. Памфлети. Листи / Упоряд. М.Г. Жулинського, П.І. Майдаченка. - 925 с. 